\title{
Chromosome fusion polymorphisms in the grasshopper, Dichroplus fuscus (Orthoptera: Acrididae: Melanoplinae): Insights on meiotic effects
}

\author{
Alberto TAFFAREL ${ }^{1,2,3}$, Claudio J. BIDAU ${ }^{4}$ and Dardo A. MARTII $I^{1,2}$ \\ ${ }^{1}$ Laboratorio de Genética Evolutiva, Instituto de Biología Subtropical, Universidad Nacional de Misiones (IBS), Félix de Azara 1552 , \\ Piso 6 3300 Posadas, Misiones, Argentina; e-mails: radova@gmail.com; darmarti@gmail.com \\ ${ }^{2}$ Consejo Nacional de Investigaciones Científicas y Técnicas (CONICET), Av. Rivadavia 1917 (C1033AAJ), Ciudad Autónoma \\ de Buenos Aires, Argentina \\ ${ }^{3}$ Comité Ejecutivo de Desarrollo e Innovación Tecnológica (CEDIT), Félix de Azara 1890, Piso 5º 3300 Posadas, Misiones, \\ Argentina \\ ${ }^{4}$ Paraná y Los Claveles, 3300 Posadas, Misiones, Argentina; e-mail: bidau50@gmail.com
}

Key words. Orthoptera, Acrididae, Dichroplus fuscus, Robertsonian fusion, grasshoppers, chiasmata, trivalents, chromosomal cline

\begin{abstract}
Robertsonian fusions account for many of the changes in the evolution of the orthopteran karyotype; in their origin, a centric fusion is involved between two acro-telocentric chromosomes, forming a single bi-armed chromosome. It is usual for these rearrangements to be associated with profound changes in meiosis, such as modification in frequency and distribution of chiasmata. Dichroplus fuscus is a South American grasshopper with a wide distribution. In this work we analyzed nine populations from Misiones Province, north-eastern Argentina. This species presents a standard karyotype of $2 n=23 / 24(\delta / 0)$ with all chromosomes acro-telocentric and an X0/XX chromosomal sex determining mechanism. This standard karyotype has been modified by the occurrence of two Robertsonian fusions involving chromosomes $1 / 3$ and $2 / 4$; values of fusions per individual (fpi) show a significant increase in the presence of karyotypic polymorphisms towards southern populations. In individuals showing chromosomal rearrangements, we observed a clear redistribution of chiasmata towards distal positions; significant differences were noted between Robertsonian homozygotes (Ho) and heterozygotes (Ht) for chromosomes arms $\mathrm{L}_{1}$ and $\mathrm{M}_{3}$, although this was not the case between Ho and $\mathrm{Ht}$ for chromosome arms $\mathrm{L}_{2}$ and $\mathrm{M}_{4}$. With regard to the orientation of trivalents, values obtained for non-convergent orientation were low.
\end{abstract}

\section{INTRODUCTION}

Closely related species often differ in karyotype, either numerically or structurally (Rieseberg, 2001). The analysis of chromosomal variability and its role in natural populations, as well as its potential contribution to reproductive isolation, is a controversial topic in evolutionary studies. Even so, such variability can be highly useful in attempts to establish relationships among taxa (White, 1973, 1978; Hedrick, 1981; Levin, 2002).

Robertsonian $(\mathrm{Rb})$ fusions are a specific type of chromosomal rearrangement whereby a centric fusion is involved between two acro-telocentric chromosomes forming a single bi-armed chromosome (John \& Freeman, 1975). This type of rearrangement accounts for many of the changes in chromosome number occurring during the evolution of the orthopteran karyotype (Hewitt, 1979). In wild populations, such fusions can be found either as spontaneous mutants, in polymorphic or polytypic conditions, or as interspecific differences (Bidau, 1990). However, cases of Rb polymorphisms between autosomes in orthopteran species are scarce, in contrast with those involving an autosome and the X chromosome (Castillo et al., 2010a, b); there are only six species described in the literature showing this kind of polymorphisms, all of them from the New World: Oedaleonotus enigma (Scudder, 1876), Leptysma argentina Bruner, 1906, Dichroplus pratensis Bruner, 1900, Sinipta dalmani Stål, 1861, Cornops aquaticum Bruner, 1906, and Hesperotettix viridis (Thomas, 1872) (McClung, 1917; Colombo, 2013).

$\mathrm{Rb}$ rearrangements have been considered an important factor in chromosomal speciation, with a number of models being proposed (Bickham \& Baker, 1979; Baker \& Bickham, 1986; Sites \& Moritz, 1987; Bidau, 1990). Most of these models emphasize negative heterosis of $\mathrm{Rb}$ heterozygotes; however, drastic modifications in recombination patterns that usually accompany $\mathrm{Rb}$ change have probably played a major role in the microevolutionary effects of Rb fusions (King, 1993; Brown \& O’Neill, 2010). Whatever, the role of $\mathrm{Rb}$ rearrangements in chromosome speciation remains controversial. Their effects in genetic and meiotic systems, such as recombination changes, have been tested and studied extensively in several taxonomic groups (Parker et al., 1982; Parker, 1987; Bidau, 1990; Martí \& Bidau, 1995; Bidau et al., 2001; Colombo, 2007). It is usual for these rearrangements to be associated with profound changes in meiosis (e.g. modification in frequency and distribution of chiasmata).

Some species are useful models for studying Rb rearrangements. These include the South American grasshopper, Dichroplus pratensis, and two kinds of rodents, tucotucos of the genus Ctenomys and the house mouse, Mus musculus domesticus (Bidau, 1990; Braggio et al., 1999; Bidau et al., 2001; Capanna \& Castiglia, 2004). However, the contribution of the acridoid Orthoptera to present-day 


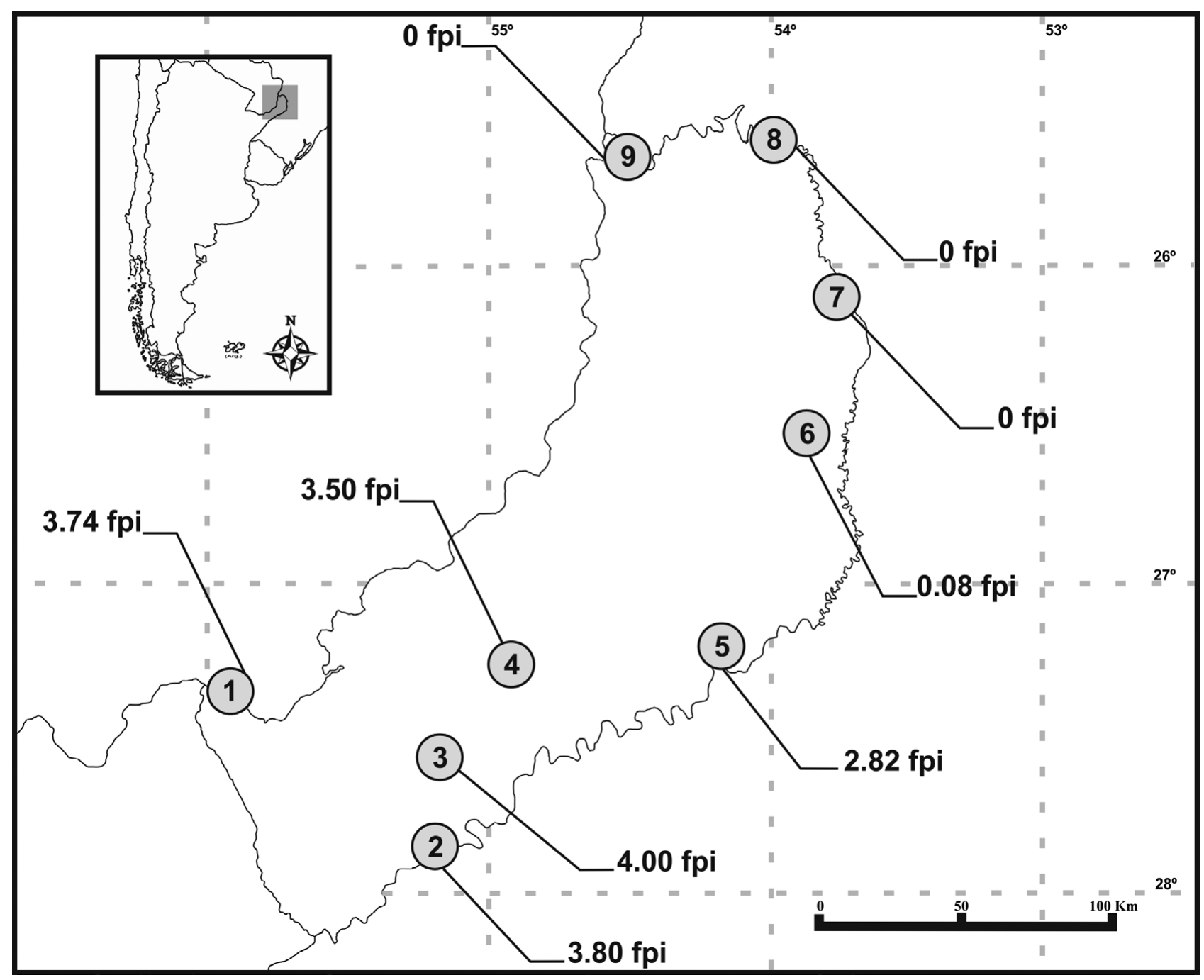

Fig. 1. Map from Misiones Province with the sampled localities and fusion per individual (fpi) values. 1 - Posadas; 2 - Itacaruaré; 3 - Picada San Javier; 4 - Oberá; 5 - El Soberbio; 6 - Tobuna; 7 - San Antonio; 8 - Andresito; 9 - Iguazú.

cytogenetics, whether in terms of structure and function of chromosomes or relevant taxonomic or evolutionary chromosome information, has made this group an especially good model for studying chromosomal changes (Bidau, 1990; Bidau \& Martí, 2010). Historically, Acrididae were divided into two groups of subfamilies, based mainly on their phallic structures: Cryptosacci and Chasmosacci (Roberts, 1941). Secondly, these groups of subfamilies were divided according to their chromosome number, the

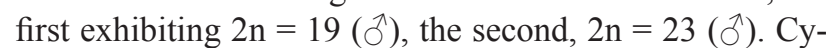
tologically, the Chasmosacci were the most stable group, unlike Cryptosacci where, although the characteristic diploid number was maintained in most of the genera, some species exhibited reductions in this number, mainly due to centric fusions (White, 1945).

The genus Dichroplus comprises 23 species including Dichroplus notatus, whose generic position is currently under review (Behrstock \& Sullivan, 2011; Eades et al., 2014). Cytogenetically, the genus displays a wide karyotypic diversity, $\mathrm{Rb}$ translocations being the main source of chromosomal change. Some species such as D. exilis, exhibit the ancestral Cryptosacci karyotype $(2 n=23 / 24$ $\widehat{\delta} /$ ) (Mesa et al., 1982), whilst $D$. silveiraguidoi displays an exceptionally low chromosome number $(2 n=8)$ (Sáez, $1957)$, D. pratensis shows a complex Rb system, polymorphic for up to seven distinct fusions between the six large chromosomes (Bidau, 1990; Bidau et al., 1991; Bidau \& Martí, 1995), and D. vittatus has a neo-XY system, the product of an X-autosome fusion (Bidau \& Martí, 2001). Dichroplus fuscus (Thunberg, 1815) is a South American grasshopper with a wide distribution, including Bolivia, Paraguay, Brazil and northern Argentina. D. fuscus belongs to the "elongatus group" that includes species with strong similarity in terms of external anatomy and colour patterns (Ronderos et al., 1968). Originally cited by Mesa et al. (1982), these authors reported variation in the diploid number, ranging from 23 to $19(\widehat{\jmath})$ due to the presence of two non-established centric fusions, as found in individuals from localities in Bolivia and Brazil. However, no information about what chromosomes were involved in the rearrangements, their polymorphic condition, behaviour or possible effects over genetic recombination were given in that work. 
TABLE 1. Geographic source and number of individuals of Dichroplus fuscus studied in the present paper.

\begin{tabular}{lccc}
\hline Population & Geographical coordinates & Number of individuals (m/f) & fpi \\
\hline 1. Posadas (POS) & $27.44 / 55.89$ & $32 / 16$ & 3.74 \\
2. Itacaruaré (ITA) & $27.90 / 55.27$ & $21 / 23$ & 3.80 \\
3. Picada San Javier (PSJ) & $27.74 / 55.26$ & $5 / 10$ & 4.00 \\
4. Oberá (OBE) & $27.64 / 54.91$ & $3 / 3$ & 3.50 \\
5. El Soberbio (SOB) & $27.29 / 54.20$ & $22 / 7$ & 2.82 \\
6. Tobuna (TOB) & $26.48 / 53.89$ & $16 / 9$ & 0.08 \\
7. San Antonio (SAN) & $26.03 / 53.80$ & $5 / 6$ & 0 \\
8. Andresito (AND) & $25.59 / 53.99$ & $16 / 13$ & 0 \\
9. Iguazú (IGZ) & $25.67 / 54.48$ & $6 / 0$ & 0 \\
\hline
\end{tabular}

Fusions per individual (fpi) in the different sampled populations, along with their latitude, longitude and number of individuals. $\mathrm{m} / \mathrm{f}-$ males/females.

The main objective of the present work is to describe the Robertsonian fusions of D. fuscus in Misiones Province, Argentina. We also analyzed the relationship between the presence of the rearrangements and the changes in chiasma frequency and localization, and $\mathrm{Rb}$ trivalent orientation, and suggest some of the possible factors governing karyotype variations in this grasshopper species.

\section{MATERIAL AND METHODS}

Nine populations, representing a total of 213 individuals (126 males and 87 females) were sampled from Misiones Province and subject to cytogenetic analysis (Fig. 1, Table 1). Testes were dissected and fixed in 3:1 (methanol : acetic acid). Male meiotic analyses were performed by squashing some testes follicles in propionic haematoxylin, whilst female mitoses were obtained following the protocol of Castillo et al. (2011). C-banding procedure was performed according to Sumner (1972) and Chromomycine $\mathrm{A}_{3}\left(\mathrm{CMA}_{3}\right)$ and DAPI (4', 6-diamidino-2-fenylindole) staining according to Schweizer (1980).

Chiasmata were scored at metaphase I in all male individuals and classified by inspection as proximal (P), interstitial (I) and distal (D), corresponding to their presence in the first, second, or third portion of the chromosome arm, respectively, when divided into three equal regions. Ten random cells were selected for each male, with only the four chromosomes involved in the rearrangements differentiated into three groups: unfused bivalents, fused trivalents (heterozygotes) and fused bivalents (homozygotes), being considered. In order to identify the chromosomes involved in the rearrangements, only bivalents and trivalents with distal chiasmata were measured. Trivalent orientation was recorded at full metaphase I as convergent or linear. Data was obtained for each of the fusions separately, and for each of the populations, taking into account the position of chiasmata.

\section{RESULTS}

\section{The standard karyotype}

Dichroplus fuscus has a standard karyotype of $2 \mathrm{n}=23$ chromosomes in males and $2 \mathrm{n}=24$ in females, with an $\mathrm{X} 0 / \mathrm{XX}$ chromosomal sex determining mechanism. All chromosomes of this Cryptosacci karyotype are acro-telocentric and include two large $\left(\mathrm{L}_{1}-\mathrm{L}_{2}\right)$, six medium-sized $\left(\mathrm{M}_{3}-\mathrm{M}_{8}\right)$, and three small chromosomes $\left(\mathrm{S}_{9}-\mathrm{S}_{11}\right)$, with the $\mathrm{X}$ chromosome being about the size of $\mathrm{L}_{2}-\mathrm{M}_{3}$ (Fig. 3a), and with $\mathrm{S}_{11}$ being the megameric bivalent (Fig. 2a-b).

$\mathrm{C}$-banding showed positive signals in the centromeric region of the entire chromosome set; bivalents $M_{5}-M_{8}$ and $\mathrm{S}_{9}-\mathrm{S}_{11}$ also showed $\mathrm{C}+$ heterochromatic blocks in their telomeric regions, as well as the $\mathrm{X}$ chromosome. A polymorphic $\mathrm{C}+$ interstitial band was evident in one chromosome of pair $\mathrm{M}_{6}$ in all analyzed individuals (Fig. 3a, d, g). Also, one female from the Andresito (AND) population was heterozygous for a $\mathrm{C}+$ heterochromatin block located in the pericentromeric region of one chromosome of pair $\mathrm{M}_{3}$ (Fig. 3a). Sequential $\mathrm{CMA}_{3} / \mathrm{DAPI}$ banding revealed $\mathrm{CMA}_{3}+$ and DAPI- bands in centromeric regions in all metaphase I bivalents. However, terminal $\mathrm{CMA}_{3}+$ DAPIbands were brighter in $\mathrm{M}_{5}, \mathrm{M}_{6}, \mathrm{~S}_{9}$ and $\mathrm{S}_{11}$ pairs. Furthermore, the $\mathrm{X}$ chromosome showed positive $\mathrm{CMA}_{3}$ signals in the pericentromeric and distal regions (Fig. 3a, b and c). The pericentromeric block in pair $\mathrm{M}_{3}$ was negative for both, DAPI and $\mathrm{CMA}_{3}$ (Fig. 3b and c), whilst the interstitial band in chromosome $\mathrm{M}_{6}$ was $\mathrm{CMA}_{3}+$ DAPI- (Fig. 3).

This standard karyotype is modified by the occurrence of two Robertsonian fusions involving chromosomes $\mathrm{L}_{1}$ and $M_{3}$ (fusion 1/3) and $L_{2}$ and $M_{4}$ (fusion 2/4), both highly symmetric, with centromeric indexes between 40 and 50 ( $m$ according to Levan et al., 1964). Autosomes involved in the fusions were identified by gross morphology, since none of them show specific cytogenetic markers (e.g. differential $\mathrm{C}$ banding (this paper) or NOR localization (Nascimento, 2009). These polymorphisms cause variation in diploid number ranging from $2 n=19 / 20$ to $2 n=23 / 24$ $(\delta /+)$. A total of six karyotypes (of nine possible), including the standard with all acro-telocentric chromosomes, were found depending on the presence of one or two fusions, and their polymorphic condition (Fig. 2c-f and Fig. 3d-i).

\section{Distribution and frequencies of Robertsonian fusions}

The presence of the rearrangements is restricted to the southernmost D. fuscus populations within the study area; six of the nine populations analyzed showed at least one of the fusions and, with the exception of the Tobuna (TOB) population, none of these had the standard karyotype.

Values of fusions per individual (fpi) showed a significant increase in terms of the presence of chromosomal polymorphisms towards the southern populations (Fig. 1, Table 1). Populations AND and Itacaruaré (ITA) (northern and southern limits of the study area) are ca. $286 \mathrm{~km}$ apart; the four northern populations [Iguazú (IGZ), AND, San Antonio (SAN) and Tobuna (TOB)] showed no fusions at all (zero fpi), or values close to zero (0.08 fpi in TOB), 

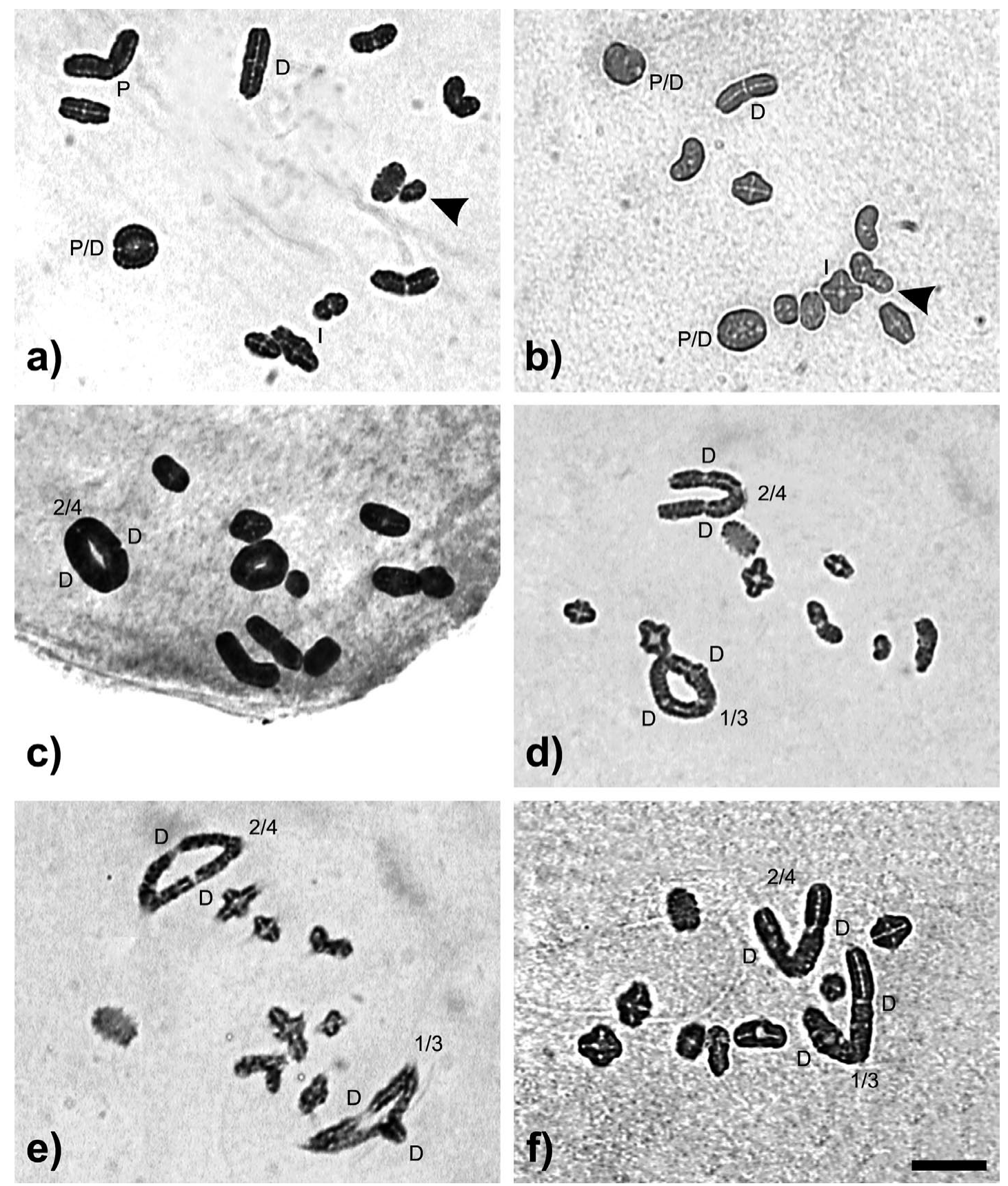

Fig. 2. Dichroplus fuscus meiosis with different karyotypes. $\mathrm{a}-\mathrm{b}$ - standard karyotype from the Andresito population; c - homozygous for fusion 2/4 from the El Soberbio population; $d$ - homozygous for fusion 1/3 and heterozygous for fusion 2/4 from the Itacaruaré population; e - homozygous for both fusions from Posadas; $\mathrm{f}$ - heterozygous for both fusions from El Soberbio. P - proximal; I - interstitial; D - distal. Arrowhead indicates the megameric bivalent. Bar $=10 \mu \mathrm{m}$.

whilst the four southern populations [Posadas (POS), ITA, Picada San Javier (PSJ) and Oberá (OBE)] showed the highest percentages of fusions per individual, 4 fpi in PSJ (the maximum possible value), $3.8 \mathrm{fpi}$ in ITA, $3.74 \mathrm{fpi}$ in POS and 3.5 fpi in OBE (Fig. 1, Table 1). The only population with intermediate values was El Soberbio (SOB), located between these two groups, with 2.82 fusions per individuals (Fig. 1, Table 1).

Fusion $1 / 3$ was found in a total of 141 individuals $(66.2 \%)$, while fusion 2/4 was found in 144 (67.6\%). Most of the analyzed individuals (65.7\% of the total) had both fusions simultaneously, either in homozygous and/or het- erozygous condition. Two individuals from SOB, one homozygous and the other heterozygous for fusion $2 / 4$, and two individuals from TOB, also heterozygous for the same fusion, were the only ones with one of the rearrangements in their chromosome complement.

\section{Chiasma analyses and trivalent orientation}

Telocentric L bivalents showed a predominant bichiasmate configuration, usually the $\mathrm{P} / \mathrm{D}$ one, only sometimes I/D, and rarely P/I. Monochiasmate L bivalents were also rare, usually exhibiting a D or P chiasma, and with I ones the least frequent. $\mathrm{M}$ bivalents rarely form more than one chiasma, in variable position, the most frequent being $\mathrm{D}$ 


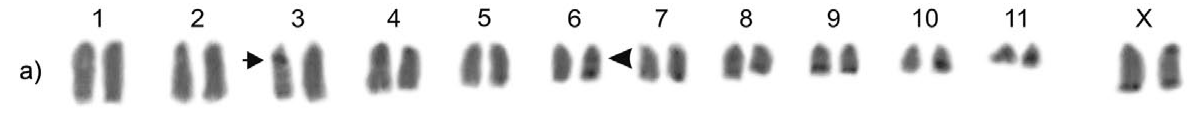

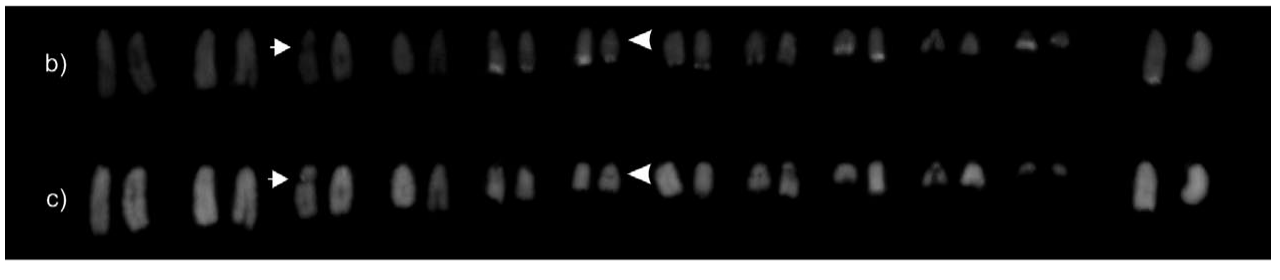

d)
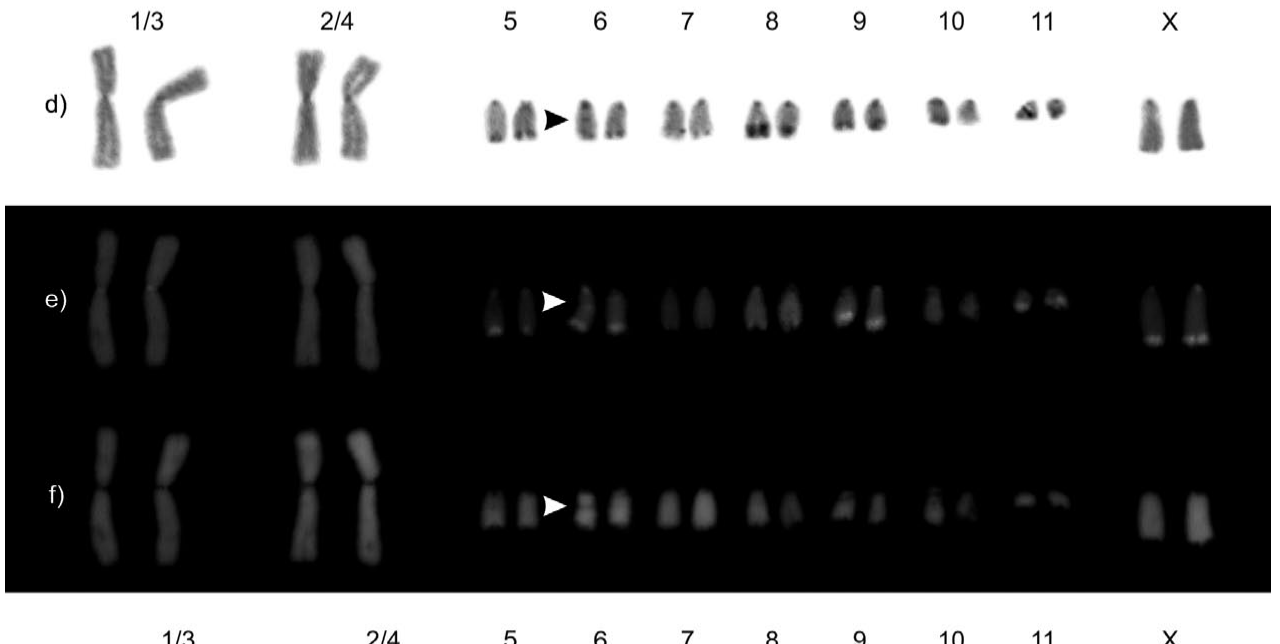

g)
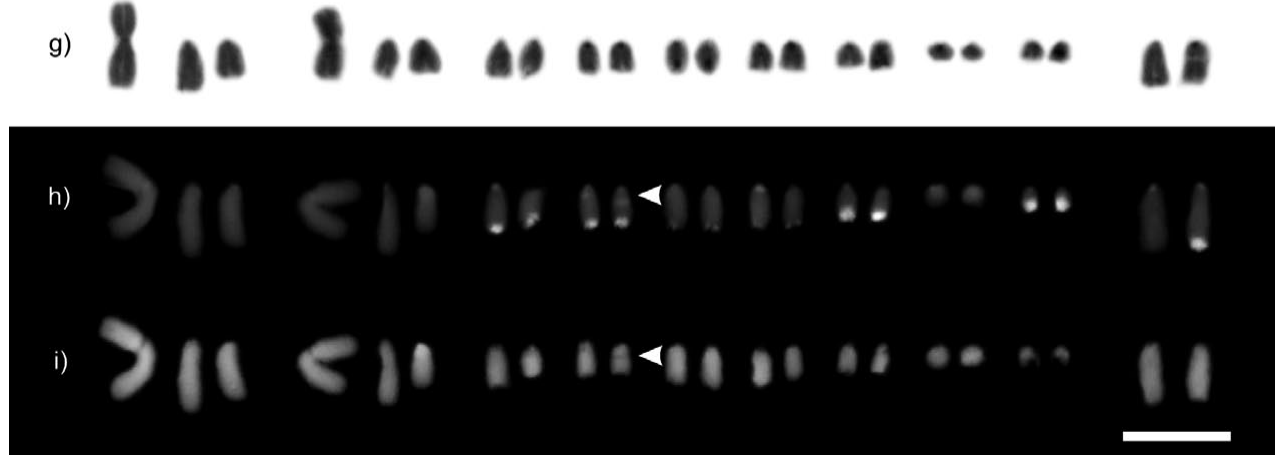

Fig. 3. Karyotypes of three different females. a-c - standard karyotypes of a female from the Andresito population with C-banding, $\mathrm{CMA}_{3}$ and DAPI staining, respectively; $\mathrm{d}-\mathrm{f}-$ female from Posadas homozygous for both fusions (d-C-banding; $\mathrm{e}-\mathrm{CMA} ; \mathrm{f}-\mathrm{DAPI}$ ); $\mathrm{g}-\mathrm{i}$ - female heterozygous from the El Soberbio population ( $\mathrm{g}-\mathrm{C}$-banding; $\left.\mathrm{h}-\mathrm{CMA}_{3} ; \mathrm{i}-\mathrm{DAPI}\right)$. Arrow indicates pericentromeric $\mathrm{C}+$ block in pair $\mathrm{M}_{3}$; arrowheads indicate interstitial $\mathrm{C}+$ band in pair $\mathrm{M}_{6}$. $\mathrm{Bar}=10 \mu \mathrm{m}$.

ones. There were only a few cells where chromosome $\mathrm{M}_{3}$ presented a bichiasmate configuration (Fig. 2a, b; Table 2).

In individuals displaying chromosomal rearrangements (carriers), we observed a profound redistribution of chiasmata towards distal positions (Fig. 2c-f; Table 2). When comparison between the three karyotypes was made for each chromosome arm in order to test the significance of these differences in chiasma distribution, highly significant values were obtained (Table 4). Differences between homozygotes (Ho) and heterozygotes $(\mathrm{Ht})$ for chromosomes arms $\mathrm{L}_{1}$ and $\mathrm{M}_{3}$ were also significant, although this was no so between $\mathrm{Ho}$ and $\mathrm{Ht}$ for chromosome arms $\mathrm{L}_{2}$ and $\mathrm{M}_{4}$ (Table 4).

Lastly, with regard to the orientation of trivalents, values obtained for non-convergent orientation were low, and did not exceed $12.5 \%$ in terms of the total number of heterozygotes analyzed (Table 3 ).

\section{DISCUSSION}

Among the effects of $\mathrm{Rb}$ fusions on genetic recombination, the frequency and distribution of chiasmata are usually affected, as has been observed in a number of widely different animal species (Capanna et al., 1976; Colombo, 1987; Bidau, 1990; Bidau et al., 2001). This is mainly because the establishment of a polymorphism will depend largely on the redistribution of chiasmata in the chromosomes involved, a necessary prerequisite for the correct orientation and segregation of linkage groups in metaphase I and anaphase I, respectively, and thus overcoming the difficulties during meiosis. There are several precedents in Orthoptera that demonstrate the relationship between the 
TABLE 2. Chiasma distribution and frequency in standard (St) and Robertsonian homozygotes (Ho) and heterozygotes (Ht) of $\mathrm{Di}$ chroplus fuscus.

\begin{tabular}{|c|c|c|c|c|c|c|}
\hline \multirow{2}{*}{ Chromosome Arm } & \multicolumn{3}{|c|}{$\mathrm{L}_{1}$} & \multicolumn{3}{|c|}{$\mathrm{M}_{3}$} \\
\hline & $\mathrm{St}$ & Ho & $\mathrm{Ht}$ & $\mathrm{St}$ & Ho & $\mathrm{Ht}$ \\
\hline $\mathrm{P}$ & 373 & 31 & 8 & 158 & 25 & - \\
\hline I & 6 & 21 & 14 & 62 & 23 & 1 \\
\hline $\mathrm{D}$ & 410 & 567 & 88 & 233 & 548 & 109 \\
\hline Qx Fr & 1.75 & 0.99 & 1.00 & 1.01 & 0.96 & 1.00 \\
\hline $\mathrm{n}$ & 450 & 620 & 110 & 450 & 620 & 110 \\
\hline$\underline{\mathrm{N}}$ & 45 & 62 & 11 & 45 & 62 & 11 \\
\hline \multirow{2}{*}{ Chromosome Arm } & \multicolumn{3}{|c|}{$\mathrm{L}_{2}$} & \multicolumn{3}{|c|}{$\mathrm{M}_{4}$} \\
\hline & $\mathrm{St}$ & Ho & $\mathrm{Ht}$ & St & Ho & $\mathrm{Ht}$ \\
\hline $\bar{P}$ & 268 & 18 & 10 & 145 & 18 & 3 \\
\hline I & 10 & 20 & 5 & 62 & 18 & 11 \\
\hline $\mathrm{D}$ & 323 & 470 & 245 & 202 & 470 & 246 \\
\hline Qx Fr & 1.47 & 0.99 & 1.00 & 1.00 & 0.99 & 1.00 \\
\hline $\mathrm{n}$ & 410 & 510 & 260 & 410 & 510 & 260 \\
\hline$\underline{N}$ & 41 & 51 & 26 & 41 & 51 & 26 \\
\hline
\end{tabular}

symmetry of the meiotic configuration and orientation of the trivalent, there being a strong positive correlation between the presence of proximal and interstitial chiasmata, and the frequency of linear orientation of trivalents (Mirol \& Bidau, 1994; Colombo, 2009). There is also a correlation between the frequency of non-linear orientation in heterozygotes, and a possible negatively heterotic effect caused by the increased production of unbalanced and/or diploid/polyploid sperm (Mirol \& Bidau, 1994).

Such effects have been observed in both South American Orthoptera and Mus musculus domesticus: a marked decrease in proximal chiasmata accompanied by a redistribution of the same from their proximal positions to the distal region, and very low values of non-convergent orientation in the heterozygotes resulting from fusions. In the widespread Robertsonian system of $D$. pratensis, a reduction not only in the number of proximal chiasmata in the chromosomes involved in the rearrangements but also on

TABLE 3. Percentages of non-convergent orientation ( $\%$ NCO) of $D$. fuscus trivalents in each of the populations that had Robertsonian heterozygotes along with their chiasma distribution and frequencies.

\begin{tabular}{lcccccc}
\hline & $\% \mathrm{NCO}$ & $\mathrm{P}$ & $\mathrm{I}$ & $\mathrm{D}$ & $\mathrm{n}$ & $\mathrm{N}$ \\
\hline $\begin{array}{l}\text { Posadas } \\
\mathrm{L}_{1} / \mathrm{M}_{3}\end{array}$ & $12.5 \%$ & - & 0.25 & 0.75 & 16 & 2 \\
$\mathrm{~L}_{2} / \mathrm{M}_{4}$ & $8 \%$ & 0.4 & - & 0.6 & 64 & 7 \\
$\begin{array}{l}\text { Itacaruaré } \\
\mathrm{L}_{2} / \mathrm{M}_{4}\end{array}$ & $12.16 \%$ & 0.44 & - & 0.56 & 74 & 2 \\
Tobuna & & & & & & \\
$\mathrm{L}_{2} / \mathrm{M}_{4}$ & $8.3 \%$ & 0.25 & 0.25 & 0.5 & 24 & 2 \\
El Soberbio & & & & & & \\
$\mathrm{L}_{1} / \mathrm{M}_{3}$ & $10.8 \%$ & - & 0.15 & 0.85 & 93 & 9 \\
$\mathrm{~L}_{2} / \mathrm{M}_{4}$ & $12 \%$ & 0.16 & 0.18 & 0.66 & 183 & 17 \\
\hline Total & $11 \%$ & 0.20 & 0.13 & 0.67 & 454 & 39 \\
\hline $\mathrm{N}$
\end{tabular}

$\mathrm{N}$ - total number of individuals; $\mathrm{n}$ - total number of cells; $\mathrm{P}-$ proximal; I - interstitial; D - distal. the total number of crossovers in both males and females was observed; in addition, no significant differences occurred between homozygous and heterozygous $\mathrm{Rb}$ configurations (Bidau, 1990; Martí \& Bidau, 1995). In the case of the leptysmine grasshopper, Leptysma argentina, polymorphic for a fusion between autosomes 3 and 6, similar effects were observed (Colombo, 1987), although there was a marked decrease in chiasmata, accompanied by a relocation of the same towards more distal positions in the chromosome arms involved; the extent of these two effects was not the same in the heterozygous and homozygous, being less pronounced in the latter (Colombo, 1987). Studies conducted on Mus musculus domesticus, polymorphic and/ or polytypic for numerous $\mathrm{Rb}$ rearrangements, have also described a negative correlation between the occurrence of the fusions and the chiasma frequencies. Furthermore, a displacement of chiasmata towards distal ends in Rb bivalents was observed, with all trivalents showing the opposite behavior: a significant increase of $\mathrm{P}$ and I (Bidau et al., 2001, Dumas \& Britton-Davidian, 2002). The general effects found in these three species, along with those de-

TABle 4. Chiasma frequency analyses. For each chromosome arm, two comparisons of chiasma distribution were performed; one between the three observed karyotypes, and the other between $\mathrm{Rb}$ trivalents and bivalents.

\begin{tabular}{ccccc}
\hline Chromosome arm & Comparison & $X^{2}{ }_{C}$ & $\mathrm{df}$ & $p$ \\
\hline \multirow{2}{*}{$\mathrm{L}_{1}$} & St - Ho - Ht & 329 & 4 & 0.001 \\
& Ht - Ho & 21.56 & 2 & 0.001 \\
$\mathrm{M}_{3}$ & St - Ho - Ht & 264.41 & 4 & 0.001 \\
& Ht - Ho & 9.75 & 2 & 0.001 \\
& St - Ho - Ht & 307.7 & 4 & 0.001 \\
$\mathrm{~L}_{2}$ & Ht - Ho & $2.18^{*}$ & 2 & 0.001 \\
& St - Ho - Ht & 301.9 & 4 & 0.001 \\
$\mathrm{M}_{4}$ & Ht - Ho & $5.84^{*}$ & 2 & 0.001 \\
\hline
\end{tabular}

$\overline{X^{2}{ }_{C} \text { - Contingency chi-square; } \mathrm{df}-\text { degrees of freedom; } p \text { - sta- }}$ tistical significance; $*$ - non significant. 
scribed in the present study, are very similar in terms of intrachromosomal effects, as they are a necessary condition for the maintenance of such polymorphisms.

As we have shown, the total percentage of trivalents with non-convergent orientation was very low $(<<12.5 \%)$, probably aided by the redistribution of chiasmata, and the high symmetry of the newly arisen metacentric chromosomes. With the exception of $\mathrm{L}_{1} / \mathrm{M}_{3}$ trivalents with nonconvergent orientation as found in the SOB population, all other trivalents presented a high percentage of $\mathrm{P}$ and I chiasmata; this result may be attributable to misidentification of chiasmata position. There are different opinions regarding the mechanisms underlying this phenomenon. In his work on L. argentina, Colombo (1987) found a doubly heterozygous individual for fusion $3 / 6$ and a spontaneous fusion between chromosomes 5 and 7 . The latter showed no significant differences in the number and position of chiasmata in relation to the standard telocentric chromosomes. In addition, trivalent behavior at metaphase I was highly irregular. Colombo (1987) raised the possibility that the modifications on chiasma frequency and distribution in heterozygotes of the $3 / 6$ fusion carriers were determined by a later adaptation to the polymorphic condition rather than a direct effect of the fusion itself. However, cases of spontaneous $\mathrm{Rb}$ mutants are scarce, and the ones we observed may be those that have been able to overcome the prevailing meiotic difficulties, and also that chiasma modifications occur for mutants heterozygous for other rearrangements (i.e. inversions and fissions) (Parker et al., 1982; Parker, 1987). Bidau (1990, 1993), based on his observations on $D$. pratensis cytology and models of synapsis in Orthoptera and premeiotic chromosome disposition, proposed another model. Knowing that homologous chromosomes are attached close to each other in the nuclear envelope at prophase I and that chiasmata are most likely to occur in regions that pair first and remain paired longer, in metacentric chromosomes product of Robertsonian rearrangements, the centromere is no longer attached to the nuclear envelope (as in acro-telocentric ones) so that synapsis will only start at the ends of the chromosomes, increasing the chance of chiasmata occurring in distal positions. We predict that this model could also apply to D. fuscus.

Since information on $D$. fuscus geographic distribution as well as its cytogeography is scarce, it is not possible to make a direct statement as to the behaviour of its chromosomal polymorphisms. However, it is important to note two central aspects of its biology: (1) this melanopline has a very wide distribution range in South America, ranging from $9^{\circ} \mathrm{S}$ to $28^{\circ} \mathrm{S}$; and (2) the area studied in the present work represents the southern limit of the species. The analysis of fusion frequencies shows a clear increase from north to south. Furthermore, if we consider the data published by Mesa et al. (1982), the localities they note with regard to the presence of chromosomal variants for the species correspond to regions located in the southern (Passo Fundo, Brazil), eastern (Piracicaba, Brazil) and western (Cochabamba, Bolivia) range of this grasshopper's distribution. Even so, care must be taken when interpreting this information, since the authors do not described the polymorphic status of the rearrangements, nor indicate whether the variation found was observed in the three sites studied. Also in our study, the frequency of fusions between nearby populations was very similar. This probably means that these populations maintain a certain degree of gene flow with each other. The only locality with intermediate values was SOB, located between these two groups (North and South) (See Results).

The former discussion is related to a recent debate on the geographic distribution of orthopteran fusion polymorphisms. The best studied species to date is a congener of D. fuscus, D. pratensis in which several fusion polymorphisms were studied in most of its wide geographic range showing a clear central-marginal pattern: number and frequency of fusions is high in central (ecologically optimal) areas and decreases clinally to zero in marginal environments (Bidau \& Martí, 2002). The former scenario was challenged by Colombo (2012) on the basis of two other cases of fusion polymorphisms in the Acrididae, suggesting, with little proof other than geographic distribution, that observed clinal variation of fusions does not necessarily reflect a central-marginal pattern. However, as Bidau \& Martí (2013) replied, the species cited by Colombo's (2012) as examples are known chromosomally only from a small marginal fraction of their large distribution ranges. Furthermore, since the central-marginal model has many different variants (Eckert et al., 2008; Bidau \& Martí, 2013) nothing can be assumed a priori about its absence or presence without a thorough analysis of the complete species distribution. The former case also applies to our $D$. fuscus data: the presumed clinal pattern we observed may or may not be part of a larger central-marginal one and further studies are required to obtain a more complete picture.

Although the studied area represents a very small part of this species distribution, and taking into account the values of fusion per individuals observed, and that populations close to each other have very similar karyotypic constitution, it is probable that environmental factors (e.g. climatic) play a role in the distribution of the aforementioned chromosomal rearrangements (White, 1978). Another more speculative explanation of the observed patterns is that due to the reconfiguration on chiasma patterns seen in the $\mathrm{Rb}$ metacentrics (see Results), such recombination-free regions harbour newly arisen co-adapted supergenes that favour their carriers during adaptation to local ecological conditions.

ACKNOWLEDGEMENTS. The authors are grateful to E. Castillo for critical reading of the manuscript, to the three anonymous reviewers whose suggestions have substantially improved the manuscript, and to H.D. Loxdale for his helpful editorial suggestions. AT and DAM thank the Consejo Nacional de Investigaciones Científicas y Técnicas (CONICET) IBS-Universidad Nacional de Misiones for their support, and AT is very grateful to CEDIT (Comité Ejecutivo de Desarrollo e Innovación Tecnológica-Misiones) for the award of a postgraduate scholarship during his time as a $\mathrm{PhD}$ candidate at the Universidad Nacional de Córdoba, Argentina. 


\section{REFERENCES}

BAKeR R.J. \& Bickham J.W. 1986: Speciation by monobrachial centric fusions. - Proc. Natn. Acad. Sci. U.S.A. 83: 82458248.

Behrstock R.A. \& Sullivan P.H. 2011: Dichroplus notatus (Orthoptera: Acrididae): A grasshopper genus and species new to the United States. - J. Orthopt. Res. 20: 35-38.

BiCKHAM J.W. \& BAKER R.J. 1979: Canalization model of chromosomal evolution. In Swartz J.H. \& Rollins H.G. (eds): Models and Methodologies in Evolutionary Theory. - Bull. Carnegie Mus. Nat. Hist. 13: 70-84.

BIDAU C.J. 1990: The complex Robertsonian system of Dichroplus pratensis (Melanoplinae, Acrididae). II. Effects of the fusion polymorphisms on chiasma frequency and distribution. Heredity 64: 145-159.

BIDAU C.J. 1993: Causes of chiasma repatterning due to centric fusions. - Braz. J. Genet. 16: 283-296.

Bidau C.J. \& Martí D.A. 1995: Male and female meiosis in Robertsonian heterozygotes of Dichroplus pratensis (Acrididae). In Brandham P.E. \& Bennett M.D. (eds): Kew Chromosome Conference IV. Royal Botanic Gardens, Kew, UK, pp. 381396.

Bidau C.J. \& Martí D.A. 2001: Meiosis and the Neo-XY system of Dichroplus vittatus (Melanoplinae, Acrididae): a comparison between sexes. - Genetica 110: 185-194.

BidAu C.J. \& Martí D.A. 2002: Geographic distribution of Robertsonian fusions in Dichroplus pratensis (Melanoplinae, Acrididae): the central-marginal hypothesis reanalyzed. $-C y$ togen. Genome Res. 96: 66-74.

BidAU C.J. \& MARTí D.A. 2010: 110 years of orthopteran cytogenetics, the chromosomal evolutionary viewpoint, and Michael White's signal contributions to the field. - J. Orthopt. Res. 19: $165-182$.

BIDAU C.J. \& MARTí D.A. 2013: The central-marginal hypothesis in acridid Orthoptera: a critique of Colmbo's (2012) article. Eur. J. Entomol. 110: 181-185.

Bidau C.J., Belinco C., Mirol P. \& Tosto D. 1991: The complex Robertsonian system of Dichroplus pratensis (Melanoplinae, Acrididae). I. Geographic distribution of fusion polymorfisms. - Genet. Sel. Evol. 23: 353-370.

Bidau C.J., Giménez M.D., Palmer C.L. \& Searle J.B. 2001: The effects of Robertsonian fusions on chiasma frequency and distribution in the house mouse (Mus musculus domesticus) from a hybrid zone in northern Scotland. - Heredity 87: 305-313.

Braggio E., Ipucha C., Gimenez M.D. \& Bidau C.J. 1999: Una posible zona híbrida en Ctenomys talarum de la Provincia de Buenos Aires, Argentina (Rodentia, Ctenomyidae). In: Actas del $29^{\circ}$ Congreso de la Sociedad Argentina de Genética. Rosario, Santa Fe.

Brown D.J. \& O’NeILl R.J. 2010: Chromosomes, conflicts and epigenetics: chromosomal speciation revisited. - Annu. Rev. Genom. Hum. Genet. 11: 291-316.

Capanna E. \& Castiglia R. 2004: Chromosomes and speciation in Mus musculus domesticus. - Cytoget. Genome Res. 105: 375-384.

Capanna E., Gropp A., Winking H., Noack G. \& Civitelli M.V. 1976: Robertsonian metacentrics in the mouse. - Chromosoma 58: 341-353.

Castillo E.R.D., Bidau C.J. \& Martí D.A. 2010a: Neo-sex chromosome diversity in Neotropical melanoplinae grasshoppers (Melanoplinae, Acrididae). - Genetica 138: 775-786.

Castillo E.R.D., Bidau C.J. \& Martí D.A. 2010b: Sex- and neosex chromosomes in Orthoptera: a review. - J. Orthopt. Res. 19: $213-231$.
Castillo E.R.D., Taffarel A. \& Martí D.A. 2011: An alternative technique for mitotic grasshopper karyotyping: Fluorescent and C-banding in Adimantus ornatissimus (Orthoptera: Acrididae). - Rev. Cienc. Tecnol. 16: 31-35.

Colombo P.C. 1987: Effects of centric fusions on chiasma frequency and position in Leptysma argentina (Acrididae: Orthoptera). I. Spontaneous and stable polymorphic centric fusions. - Genetica 72: 171-179.

Colombo P.C. 2007: Effects of polymorphic Robertsonian rearrangements on the frequency and distribution of chiasmata in the wather-hyacinth grasshopper, Cornops aquaticum (Orthoptera: Acrididae). - Eur. J. Entomol. 104: 653-659.

Colombo P.C. 2009: Metaphase I orientation of Robertsonian trivalents in the water-hyacinth grasshopper, Cornops aquaticum (Acrididae). - Genet. Mol. Biol. 32: 91-95.

Colombo P.C. 2012: Against the central-marginal model: Three cases in chromosomally polymorphic grasshoppers (Orthoptera: Acrididae). - Eur. J. Entomol. 109: 317-324.

Colombo P.C. 2013: Micro-evolution in grasshoppers mediated by polymorphic Robertsonian translocations. - J. Insect Sci. 13: 43.

Dumas D. \& BRitTon-DaVidian J. 2002: Chromosomal rearrangements and evolution of recombination: comparison of chiasma distribution patterns in standard and Robertsonian populations of the house mouse. - Genetics 162: 1355-1366.

Eades D.C., Otte D., Cigliano M.M. \& Braun H. 2014: Orthoptera Species File. Version 5.0/5.0. [February 8, 2014]. <http:// Orthoptera.SpeciesFile.org>

ECKert C.G., SAmis K.E. \& Lougheed C. 2008: Genetic variation across species' geographical ranges: the central-marginal hypothesis and beyond. - Mol. Ecol. 17: 1170-1188.

HEDRICK P.W. 1981: The establishment of chromosomal variants. - Evolution 35: 322-332.

HewitT G.M. 1979: Orthoptera. Grasshoppers and crickets. In John B. (ed.): Animal Cytogenetics 3. Insecta 1. Gebruder Borntraeger, Berlin-Stuttgart, $170 \mathrm{pp}$.

John B. \& FreEMAN M. 1975: Causes and consequences of Robertsonian exchange. - Chromsoma 52: 123-136.

KInG M. 1993: Species Evolution. The Role of chromosome change. Cambridge University Press, Cambridge, 336 pp.

Levan A., Fredgra K. \& Sandberg A.A. 1964: Nomenclature for centromeric position on chromosomes. - Hereditas $\mathbf{5 2}$ : 201-220.

LeVIN D.A. 2002: The Role of Chromosomal Change in Plant Evolution. Oxford Series in Ecology and Evolution. Oxford University Press, $230 \mathrm{pp}$.

Martí D.A. \& Bidau C.J. 1995: Male and female meiosis in a natural population of Dichroplus pratensis (Acrididae) polymorphic for Robertsonian translocations: A study of chiasma frequency and distribution. - Hereditas 123: 227-235.

McClung C. 1917: The multiple chromosomes of Hesperotettix and Mermiria (Orthoptera). - J. Morphol. 29: 519-605.

Mesa A., Ferreira A. \& Carbonell C.S. 1982: Cariología de los Acridoideos Neotropicales: estado actual de su conocimiento y nuevas contribuciones. - Annls Soc. Entomol. Fr. 18: 507526.

Mirol P.M. \& BidAu J.C. 1994: Non-random patterns of non-disjuntional orientation in trivalents of multiple Robertsonian heterozygotes of Dichroplus pratensis (Acrididae). - Genetica 92: $155-164$.

Nascimento J.M. Do 2009: Análise cariotípica, heterocromatina constitutiva e frequência de expressão das RONs em duas espécies de Melanoplinae (Orthoptera: Acrididae). M.Sc. Thesis, Universidade Federal de Pernambuco, Brazil, 75 pp. 
PARKER J.S. 1987: Increased chiasma frequency as a result of chromosome rearrangement. - Heredity 58: 87-94.

Parker J.S., Palmer R.W., Whitehorn M.A.F. \& Edgar L.A. 1982: Chiasma frequency effects of structural chromosome change. - Chromosoma 85: 673-686.

RIESEBERG L.H. 2001: Chromosomal rearrangements and speciation. - Trends Ecol. Evol. 16: 351-358.

RoBERTs H.R. 1941: A comparative study of the subfamilies of the Acrididae (Orthoptera) primarily on the basis of their phallic structures. - Proc. Acad. Nat. Sci. Philad. 93: 201-246.

Ronderos R.A., Carbonell C.S. \& Mesa A. 1968: Revisión de las especies del género Dichroplus Stål del grupo elongatus. Revta Mus. La Plata 10: 271-325.

SÁEZ F.A. 1957: An extreme karyotype in an orthopteran insect. - Am. Nat. 41: 259-264.
SCHweIzer D. 1980: Simultaneous fluorescent staining of R-bands and specific heterochromatic regions (DA/DAPI bands) in human chromosomes. - Cytogenet. Cell Genet. 27: 190-193.

Sites J.W. \& Moritz C. 1987: Chromosomal evolution and speciation revisited. - Syst. Zool. 36: 153-174.

SuMNER A.T. 1972: A simple technique for demonstrating centromeric heterochromatin. - Exp. Cell Res. 75: 304-306.

White M.J.D. 1945: Animal Cytology and Evolution. The Macmillan Company, New York, 375 pp.

White M.J.D. 1973: Animal Cytology and Evolution. 3rd ed. Cambridge University Press, Cambridge, $961 \mathrm{pp}$.

White M.J.D. 1978: Modes of Speciation. W.H. Freeman, San Francisco, $455 \mathrm{pp}$.

Received February 24, 2014; revised and accepted July 14, 2014 Prepublished online October 20, 2014 